\title{
TIPping the Scales towards Greater Employment Chances? Evaluation of a Trial Introduction Program (TIP) for Newly-Arrived Immigrants based on Random Program Assignment*
}

\author{
Pernilla Andersson Joona and Lena Nekby ${ }^{\uparrow}$
}

\begin{abstract}
A Trial Introduction Program (TIP) for newly-arrived immigrants to Sweden was implemented from October 2006 to June 2008 in order to meet the main criticisms directed at existing introduction programs. Two primary innovations were introduced, flexible language instruction parallel with other labor market activities at the Public Employment Service (PES) and intensive counseling and coaching by PES caseworkers with considerably reduced caseloads. Within participating municipalities, newly-arrived immigrants were randomly assigned into TIP (treatment) or regular introduction programs (control). Results indicate significant treatment effects on the probability of attaining regular employment as well as the probability of entering intermediate PES training programs. Hazard rates into PES training programs were also significantly higher for participants in TIP in comparison to participants in regular introduction programs.
\end{abstract}

Keywords: Labor Market Policy Evaluation, Integration, Introduction Programs, Experiment

JEL Codes: J15, J64, J68, J61, C41

\footnotetext{
* The authors are grateful for comments from Peter Skogman Thoursie, Lena Schröder, Eskil Wadensjö, Gülay Özcan and seminar participants at the Department of Economics, Stockholm University, the Institute for Labour Market Policy Evaluation (IFAU) and the Ministry of Employment.

${ }^{\uparrow}$ Pernilla Andersson Joona, Swedish Institute for Social Research (SOFI) and Stockholm University Linnaeus Center for Integration Studies (SULCIS), e-mail: pernilla.andersson@ sofi.su.se.

Lena Nekby, Department of Economics, Stockholm University, SULCIS and IZA Research Fellow, e-mail: lena.nekby@ne.su.se.
} 


\section{Introduction}

Facilitating the transition from immigration (into the country) to integration (into the labor market) is an important policy issue for many European countries. Sweden, like the other Nordic countries, has set up introduction programs to assist newly-arrived immigrants in this process. These programs, which in Sweden target immigrants granted permanent residency due to political asylum (refugee status) or on humanitarian grounds (as well as tied movers arriving within two years of the main applicant) have a dismal track record in terms of transitions to regular unsubsidized employment. In order to combat the numerous problems associated with introduction programs, a Trial Introduction Program (TIP) was implemented from October 2006 to June 30, 2008 in three Swedish municipalities with an experimental set up including random program assignment. The purpose of the trial program was to considerably shorten the time from granted permanent residency to regular employment in the Swedish labor market. The main elements of the trial introduction program included earlier registration of newlyarrived immigrants in the Public Employment Services (PES) (within three months of granted residency permits), flexible language instruction parallel with other active labor programs at the PES and intensive counseling and coaching by PES caseworkers with considerably reduced workloads. The purpose of this study is to evaluate if participation in the trial introduction program improved the employment prospects of newly-arrived immigrants in comparison to participants of regular introduction programs (the control group). To our knowledge, no immigrant integration policy measure has previously been evaluated using experimental methods.

Introduction programs have been offered to newly-arrived immigrants in Sweden since the late 1960s. These programs aim to not only assist immigrants into the labor market via language instruction and active labor market programs (ALMPs) such as vocational training, job-search courses, subsidized employment and validation of pre-immigration education and work experience, but have also increasingly come to include social orientation courses such as civics and history courses and information about the norms, values and cultural traditions of the host country. Introduction programs are primarily administered by municipal governments but often in conjunction with other actors. In Sweden, for example, the Swedish PES, the Swedish Migration Board, the Swedish Association of Local Authorities and Regions (SKL) and the Swedish National Association for Education signed a central agreement concerning 
joint responsibility for introduction programs in 2001. In addition, there are decentralized agreements between the main actors in most municipalities. The decentralized responsibility for introduction programs implies a great deal of heterogeneity in the exact content of introduction programs across municipalities as well as the actors involved in these programs. Participation in introduction programs is associated with some form of remuneration, an introduction subsidy which can be withdrawn due to non-compliance or non-participation. All introduction programs are time-limited, normally for a maximum of 24 months, implying that immigrants are phased over to general labor market programs as well as general social services upon completion of introduction programs.

Despite being seen as an important component of the integration process for newly-arrived immigrants, introduction programs have recently come under heavy critique (Board of Integration, 2002, 2004, 2005, 2007b; Swedish National Audit Office, 2006; Statens Offentliga Utredningar (SOU), 2003, 2008; Swedish Association of Local Authorities and Regions (SKL), 2006, 2007a, 2007b; Svantesson, 2006; Svantesson et al 2006; Åslund et al., 2007). Concern about the efficacy of immigrant introduction programs stems from low employment levels of immigrants with short duration of residence. Only 60 percent of male immigrants and 40 percent of female immigrants with one to four years duration of residence were employed in 2006. Employment rates are even more dismal for immigrants that participated in introduction programs, only 30 percent of male immigrants and 20 percent of female immigrants were employed three years after completion of introduction programs (Board of Integration, 2007).

A recent overview of the numerous reports and studies assessing introduction programs lists a number of the problems that reviewers agree upon with regards to introduction programs (National Thematic Network on Asylum and Integration, 2008). The report highlights weak ties to the labor market, a lack of cooperation and coordination between the different actors responsible for newly-arrived immigrants, isolated rather than coordinated and comprehensive activities, poor language instruction as well as language instruction provided in isolation from other more labor-oriented programs at the PES. ${ }^{1}$ In addition successful completion of language courses is normally required before activation in active labor market programs at the PES. Finally, introduction programs have been criticized for their lock-in effects. Immigrants are

\footnotetext{
${ }^{1}$ For instance, ninety percent of participants in introduction programs receive language instruction during their first year in Sweden but only 27 percent successfully complete these courses within the first year of instruction (Board of Integration, 2007c).
} 
often placed in one form of program after another, many times in education programs with weak ties to the labor market and where the efficacy of these courses in terms of promoting transitions to regular employment can be questioned. ${ }^{2}$

In order to meet the problems associated with introduction programs, a trial introduction program was commissioned by the government and implemented in October 2006 in three Swedish counties (Kronoberg, Stockholm and Skåne). The purpose of the trial introduction program (TIP) was to considerably shorten the time from entry into Sweden to entry into the regular labor market. In order to do so, the trial introduction program focused on improving the coordination between the two most central actors in the introduction of newly-arrived immigrants, namely Swedish municipalities and the PES. ${ }^{3}$ The trial program also encouraged early registration of newly-arrived immigrants at the PES (within three months of granted permanent residency), flexible provision of language instruction simultaneously with other active labor market programs at the PES and intensive coaching and counseling by PES caseworkers. These caseworkers, recruited specifically for the trial introduction program, were given additional training to meet the specific needs of newly-arrived immigrants and were granted considerably lighter caseloads than that normally required of PES caseworkers.

In order to facilitate a causal evaluation of participation in the trial introduction program on a number of outcomes, an experimental set-up was employed. ${ }^{4}$ Municipal PES offices in the participating counties, after determining eligibility to TIP, randomly assigned newly-arrived immigrants into the trial program (TIP) or the control group (regular introduction programs). ${ }^{5}$ This experimental setup bypasses many of the problems normally associated with evaluating labor market programs such as selective participation into the program, non-random sorting of

\footnotetext{
${ }^{2}$ An illustrative example of this phenomenon is the following. 20-25 percent of immigrants participating in basic adult education courses in 1997 were university graduates, 50 percent of which participated for more than five terms (Board of Integration, 2006). See also Schröder (2007) for an overview and critique of integration policies in Sweden.

${ }^{3}$ The Swedish Public Employment Service is an agency commissioned by the government to match job seekers with employers and to assist the unemployed in finding employment. The Employment Service is divided into 68 labour market regions and has over 700 offices across Sweden.

${ }^{4}$ An external evaluation of the trial introduction program was part of the required stipulations established for the trial introduction program (Swedish Public Employment Service, 2007a). In addition, it was stated that the external research group should be brought in at an early stage of the planning process in order to facilitate a set up conducive for proper evaluation of the trial program. As such, we were able to convince the PES to employ an experimental set up with random program assignment. To our knowledge, this is one of the first programs administered by the Swedish PES evaluated using experimental methods. Together with the PES we were able to convince 9 of the 28 municipalities in participating counties to use the experimental setup. This study is based on these nine counties. See Andersson Joona and Nekby (2009) for an initial mid-program evaluation including a comparison of results with non-participating counties.

${ }^{5}$ Random assignment into TIP or the control group was the responsibility of PES office managers.
} 
newly arrived immigrants to different regions of Sweden, differences across municipalities in the specific components of introduction programs, differences across PES offices in for example average caseworker experience with newly-arrived immigrants, differences in the coordination and cooperation between the PES and municipal governments across municipalities and differences in local labor market conditions.

Previous studies in Sweden on active labor market programs (ALMPs) targeted towards immigrants include Svantesson and Aranki (2006) who use survey data on PES caseworkers to analyze the impact of different types of labor market programs available within introduction programs on short-term employment levels. The authors find that ALMPs closely tied to regular employment such as trainee programs and internships are associated with higher employment probabilities. The authors are unable to control for selection into introduction programs or selection into different types of ALMPs within introduction programs and can therefore not determine to what degree those enrolled in ALMPs with strong ties to the labor market are positively selected and more likely to be employed even in the absence of program participation.

Åslund and Johansson (2006) study a trial employment program for immigrants (SIN) aimed at using employment support methods developed for disabled workers. Using a difference-in difference approach to estimate program effects, results indicating that the establishment of supported employment methods in certain municipalities increased transitions from open unemployment to employment by a significant 12 percent. In addition there was a significant and positive increase in transitions from work experience programs to employment in SIN communities by 15 percent. Supported employment methods may therefore have promoted better matches between participant needs and intermediate labor market programs fostering post-program employability.

Clausen et al. (2008) analyze the effect of integration policies targeted towards newly-arrived immigrants in Denmark using timing-of-events duration models. Results indicate negative and significant lock-in effects of participation in language courses and active labor market programs on hazard rates into employment. The lock-in effects of language courses however decrease over time for participants with improved language skills during the course of the program. The program effect of language courses on the hazard rate to regular employment is large and positive for participants with improved language skills. Of the active labor market 
programs offered, only wage subsidized employment programs in the private sector were found to increase transitions into employment.

Results presented here indicate that participants of TIP have significantly higher probabilities of being registered as regularly employed at the end of the observation period. In addition, they have significantly higher probabilities of being enrolled in PES training programs than participants of regular introduction programs. Duration models confirm a program effect of TIP on hazards to PES training programs but find no significant effect on transitions to regular employment. Controlling for the intensity of contact with PES caseworkers and type of intermediary programs, however, does yield a significant and positive treatment effect on transitions to regular employment suggesting more effective counseling and coaching as well as better matches between individual training needs and PES training programs for participants of TIP.

The remainder of the paper is as follows: The next section describes in detail the trial introduction program and the experimental setup. Section 3 describes the data and empirical setup. Results are presented in Section 4 and concluding remarks in Section 5.

\section{The Trial Introduction Program for Newly-arrived Immigrants (TIP): An Experimental Setup with Random Program Assignment}

The trial introduction program for newly-arrived immigrants (TIP) was introduced on October 1, 2006 within three Swedish counties (Kronoberg, Skåne and Stockholm) and phased out on June $30,2008 .^{6}$ The purpose of the program was to "take advantage of the skills, experience and education of newly-arrived immigrants in order to considerably decrease the elapsed time from granted residency permits to entry into the Swedish labor market in comparison to the situation today" (Swedish Public Employment Service, 2007a). The trial program introduced two main innovations from regular introduction programs; intensified counseling and coaching by PES caseworkers with considerably reduced caseloads and flexible provision of language instruction.

Within the trial program, PES caseworkers were recruited and trained to work exclusively with newly-arrived immigrants. In order to facilitate more intensive contacts with participants, these

\footnotetext{
${ }^{6}$ Due to the anticipated end of the trial introduction program in June, 2008, registration into the experiment was very low towards the end of the trial period. Only 100 persons were registered in the experiment after January, 2008.
} 
caseworkers were granted considerably reduced caseloads. The normal caseload during this time period for PES caseworkers in the participating municipalities was between 200-250 cases per month. Within TIP, caseworkers handled approximately 35-40 cases on average per month, depending on municipality and PES office. ${ }^{7}$ Over and beyond intensive contact and coaching with PES caseworkers, participants in TIP were offered the same types of active labor market programs (ALMPs) available to all newly-arrived immigrants. These include job search activities, validation of foreign credentials, courses on interview techniques and writing job applications, PES training programs (usually some form of occupational education) and wage subsidized employment programs. The novelty within the trial introduction program was therefore not in terms of the general types of labor market activities offered but rather in how these activities were offered (flexible language instruction simultaneously with PES ALMPs). It is possible however that TIP participants were sorted into different specific ALMPs than participants in regular introduction programs as intensive contacts with PES caseworkers also aimed to facilitate a better understanding of the individual needs of participants and may have facilitated better matches to appropriate intermediate ALMPs.

Language instruction for newly-arrived immigrants is administered and provided by municipal governments. Commonly, successful completion of language instruction is a prerequisite for activation into PES labor market programs implying that many months, sometimes years, pass before participants in introduction programs are enrolled in active labor market programs. A goal within the trial introduction program was therefore to break the sequential setup typical of introduction programs and offer flexible language instruction parallel with more labor-oriented activation measures at the PES. Municipalities were also encouraged to establish alternative forms of language instruction better suited to the demands of the labor market such as occupation-specific language instruction.

The trial introduction program also encouraged municipalities to considerably shorten waiting times from granted residency permits to enrolment in introduction programs. Originally, a three month limit was established implying a restriction of three months between granted residency permits and enrolment into introduction programs. In practice, this restriction was relaxed early on in order to enroll a greater number of newly arrived immigrants into TIP. Finally, the trial introduction program encouraged greater coordination and cooperation

\footnotetext{
${ }^{7}$ Information based on written interviews with PES office managers in participating counties (see under e-mails in references).
} 
between the main providers of integration programs, in particular between the municipality and the PES. Participation in TIP was on a full-time basis for a maximum of one year. Participants still registered in the trial program after 12 months were phased over to regular introduction programs within the municipality and the PES.

In order to evaluate the effect of participation in the trial introduction program, an experimental setup with random program assignment was implemented in nine of the municipalities within participating counties (see Table 1). PES office managers first identified the newly-arrived immigrants eligible for participation in the trial introduction program and thereafter randomly assigned eligible participants to TIP (treatment group) or regular introduction programs (control group). Due to volume stipulations, approximately 70 percent of eligible newlyarrived immigrants were assigned to TIP and 30 percent to regular introduction programs at respective PES office. Eligibility was initially strict stipulating that participants should be between 20-64 years of age, permanent residents to Sweden and enrolled in the trial introduction program no later than three months after granted residency permits. Participants were also expected to have work experience or educations within specific occupations from home countries and, after participation in the program, be able to immediately enter the labor market.

-- Table 1 here --

In practice many of these stipulations were relaxed during the course of the trial program. In particular many municipalities dropped the requirement concerning maximum three months duration of residence in Sweden (after granted residency permits) as well as previous experience and education requirements. Possible variation across PES offices in eligibility requirements is however not problematic to our evaluation as random program assignment was at the PES office level after determination of eligibility and differences between offices over time are controlled for in estimation.

This study focuses on evaluating to what degree trial program participation affects transitions to regular (unsubsidized) employment, wage subsidized employment or regular education. In addition, we study the intermediate outcome of participation in PES training programs.

\section{Data and Empirical Setup}


The data used in estimation stems from the PES database which records information on all persons registered as unemployed at the PES. ${ }^{8}$ In this study, information is compiled on all individuals registered as participating in TIP or as members of the control group during the course of the experiment from October 1, 2006 to June 30, 2008. These individuals are continuously followed thereafter, at present until September 30, 2008. In total 1,618 newlyarrived immigrants were enrolled into the experiment during this time period. According to the stipulations established for the trial introduction program, evaluation of program effects should be based on outcomes 15 months after program enrolment, thus allowing for 12 months of program participation and an additional three months to enter the labor market (Swedish Public Employment Service, 2007a). This study will therefore be based on the 1,335 individuals who meet these requirements, of which 995 ( 74.5 percent) were enrolled into the treatment group (trial introduction program) and 340 into the control group (regular introduction programs).

The PES data provide information on the job-search status of participants, the types and duration of PES active labor market programs and reason for deregistration from PES registers. The database also contains information on personal characteristics such as gender, county of residence, age, education and country of birth. This information allows us to follow the activities of participants in both the treatment (TIP) and control group from initial registration until registration into one of the four stipulated outcomes (regular or subsidized employment, regular education or PES training) as well as any change of registered status thereafter. Information on language instruction is not available in the database as language instruction is under the jurisdiction of municipal governments and, at present, there is no linked data between municipal registers and PES registers. This implies that no information is available on the type, duration, intensity or results of language instruction included in the trial and regular introduction programs. For this reason, it is not possible to identify to what degree treatment effects are driven by changes in the provision of language instruction.

There is some uncertainty concerning treatment status for 288 persons originally assigned to the treatment group (TIP participation) due to either a change in registered PES office or due to deregistration from the experiment for reasons other than achievement of the four stipulated outcomes. Deregistration can occur due to frequent absenteeism from ALMPs, disruptive behavior or a move to a non-participating municipality. As such it is unclear to what degree

\footnotetext{
${ }^{8}$ Registration at the PES as unemployed is mandatory for all persons receiving unemployment insurance benefits as well as for all newly-arrived immigrants participating in introduction programs on introduction subsidies.
} 
these 288 newly-arrived immigrants, randomly assigned to the trial introduction program, actually were treated.

The four outcome variables of interest, regular employment, subsidized employment, regular education and labor market training, are defined according to formal PES definitions. Information from two variables in the PES database are used to define each outcome variable, registered job search status and reason for PES deregistration. See Table 2 for exact definitions of each outcome variable.

-- Table 2 here--

If assignment into treatment and control groups is truly random, a causal interpretation of participation can be found by a simple regression of each outcome variable on a binary variable measuring participation in TIP. As assignment was conditional on gender, PES office and time (date of random assignment into treatment and control groups), regressions must account for this conditional randomization by the inclusion of a dummy variable for gender, a complete set of PES office dummy variables and set of registration time dummies (month registered in the experiment). Variations of the following basic model are estimated:

$$
Y_{i}=\beta_{0}+\beta_{1} T I P+\beta_{2} \text { FEMALE }_{i}+\beta_{3} \text { PESoffice }_{i}+\beta_{4} \text { MONTH }_{i}+X_{i} \beta_{5}+\varepsilon_{i}
$$

Where $Y_{i}$ is the outcome variable of individual $i$, (regular employment, subsidized employment, regular education or PES training) defined according to the last registered notation in PES registers, TIP is a zero/one variable equal to one for individuals randomly assigned into the trial program and zero for individual assigned to regular introduction programs ( $\beta_{1}$ therefore yields the estimated program effect), FEMALE is a zero/one variable equal to one for women, PESoffice is a complete set of dummy variables indicating the PES office the individual is registered with, MONTH is a dummy variable indicating month of registration into the experiment at the PES office, $X$ is a vector of control variables described below and $\varepsilon$ is the random error component. If assignment into the trial program and the control group is random, conditional on gender, PES office and date, there should be no correlation between participation in TIP and the random error component thus facilitating a 
causal interpretation of participation in TIP on outcomes of interest. Standard errors are clustered at the PES office level in all estimations.

As a check of randomization, an expanded model is estimated adding controls for age, education (six dummy variables measuring completion of primary, secondary, uppersecondary, short post-secondary, university or $\mathrm{PhD}$ educations) and county. If assignment is truly random, inclusion of these observable characteristics should not significantly alter the estimated treatment effect. In addition, instrument variable estimation, using initial assignment into treatment (intention to treat) as an instrument for treatment (TIP participation) are estimated to control for the possible effect of non-random attrition from program participation on the treatment effect.

Duration models measuring the duration from date of registration into the experiment, i.e. into an introduction program, to date of entry into one of the stipulated outcome are also estimated using Cox proportional hazard models allowing for multiple failures. Variations of the following model are used to estimate the hazard of leaving introduction programs for stipulated outcomes:

$$
h(t)=h_{0}(t) \exp \left(\beta_{1} \text { TIP }+\beta_{2} \text { FEMALE }_{i}+\beta_{3} \text { PESoffice }_{i}+\beta_{4} \text { MONTH }_{i}+X_{i} \beta_{5}\right)
$$

where $h_{0}$ is the baseline hazard to respective outcome (regular employment, subsidized employment, regular education or PES training) for experiment participants. TIP (as described above) is an indicator equal to one for participants of the trial introduction program. Coefficient estimates are reported as hazard ratios showing the ratio between the predicted hazard for TIP participants and for control group participants, all else constant. Standard errors are clustered at the PES office level.

-- Table 3 here --

Descriptive statistics are provided in Table 3. In total, approximately 14 percent of participants in the trial program were registered as having entered unsubsidized employment at the end of the observation period, fifteen months after registration. In comparison, about 9 percent of participants in regular introduction programs were registered in regular employment. Note that 
due to the 70/30 random assignment into treatment and control groups, the sample means presented in Table 3 can be affected by varying group size across PES offices. Due to conditional randomization, regression estimates of treatment effects must control for PES office, gender and month of registration. Unadjusted sample means also indicate that participants in TIP were significantly more likely to be enrolled in PES training programs and slightly more likely to be enrolled in regular education. No differences were found between the treatment and control group in terms of subsidized employment. In total 35 percent of the treatment group and 19 percent of the control group had achieved at least one of the four defined outcomes by the end of the observation period. ${ }^{9}$

\section{Results}

\subsection{Program Effects on Outcomes}

Table 4 presents estimation results of linear probability models on respective outcome (estimated separately) focusing on treatment effects, i.e., differences in outcomes due to participation in the trial introduction program in comparison to the control group, regular introduction programs. Outcomes are measured according to the last registered status 15 months after initial registration to the experiment. Model 1 includes controls for gender, PES office and month of registration (complete set of dummy variables) to account for conditional randomization. Model 2, in addition, controls for education, age and county. Any differences between PES offices that may influence results are therefore accounted for as well as any differences over time within PES offices in eligibility requirements. Reported coefficients show the difference, in percentage points, in the probability of reaching respective outcome for participants in TIP in comparison to participants in the control group.

\section{-- Table 4 here --}

Results indicate a significant treatment effect on employment probabilities. Participation in TIP leads to a 4.1 percentage point higher probability of being regularly employed than participation in regular introduction programs (model 1). This difference increases to 5.0 percentage points with the inclusion of controls for age, education and municipality (model 2), but the increase is not significant. No treatment effect is found for subsidized employment or

\footnotetext{
${ }^{9}$ This is far short of the stipulated goals of the trial introduction program stating that at least 70 percent of participants in TIP should reach one of the defined outcomes after 12 months of possible program participation.
} 
regular education indicating no differences for participants in TIP in achieving these outcomes in comparison to the control group.

The probability of being enrolled in PES training programs is large and significant indicating that participants in TIP are much more likely (approximately 10 percentage points more likely) to gain access to intermediate training programs in comparison to participants of regular introduction programs. ${ }^{10}$

\section{Assessing the Causality of Program Participation on Achieved Outcomes}

A causal interpretation of estimated effects hinges on random assignment into the trial program as well as no selective attrition from the experiment. The first issue concerns whether or not assignment into treatment and control groups at each PES office truly was random. The second issue concerns whether or not results are influenced by persons who despite assignment into the trial program, did not participate, i.e., were not treated. This may be due to a move to another PES office within participating counties or to a non-participating county or to deregistration from PES introduction programs for reasons other than achievement of one of the four stipulated outcomes. Greater demands were placed on TIP participants in terms of more frequent contacts with PES caseworkers and more intensive coaching implying that exits from the program may be non-random.

A simple test of random program assignment is to compare estimation results, reported in Table 4) with and without controls for observable characteristics (models 1 and 2). Random program assignment implies that, on average, the characteristics (both observable and nonobservable) of individuals in the treatment and control group should be the same. This implies that the inclusion of observable characteristics in estimation should not significantly alter coefficient estimates of the treatment effect. Differences in the point estimates for model 1 and model 2 in the above estimations are indeed not significant suggesting that program assignment was random.

Direct estimation of the probability of being assigned to treatment on observable characteristics (not shown), accounting for conditional randomization, largely supports the notion that

\footnotetext{
${ }^{10}$ A multinomial logit model on the four outcomes was also estimated. Results indicate that in comparison to not achieving any of the four outcomes (reference category), TIP participants (treatment group) were much more likely to achieve regular employment, regular education and PES training programs than participants in regular introduction programs (control group). See Table A1 in Appendix for results.
} 
assignment to treatment was random. The only significant result noted was a small but slightly lower probability for older individuals to be assigned to treatment (age was associated with a 0.4 percentage point lower probability of treatment).

As mentioned earlier, 288 newly-arrived immigrants assigned to TIP may not have fully participated, i.e., been treated, for reasons stated earlier. As such, it is necessary to assess to what degree non-random attrition may influence reported results by estimating instrumental variable (IV) models. The IV estimations use initial assignment into TIP (intention to treat) as an instrument for actual treatment, based on the (credible) assumption that initial program assignment was random. Results, reported in Table A2 in the Appendix, indicate that the estimated treatment effects of trial program participation are unaltered when accounting for potential non-random attrition. ${ }^{11}$ These results suggest that that potential non-random attrition does not affect reported results in Table 4 and that these results can be interpreted as causal program effects. $^{12}$

\section{Gender Differences in Treatment Effects}

Of the 1,335 newly-arrived immigrants that were registered in the experiment, either as participants in TIP or in the control group, approximately 28 percent were female (375 persons). As treatment effects may differ by gender, linear probability models on respective outcome are re-estimated separately for male and female participants.

Results shown in Table 5 indicate that earlier reported results regarding program effects on regular employment are largely driven by treatment effects for men. Male participants of TIP have a 5.6 percentage point higher probability of being registered as regularly employed in comparison to participants of regular introduction programs (model 2). No program effect on employment probabilities was found for female participants. Both male and female participants of TIP have higher chances of being registered in PES training programs, although the size of the effect is twice as large for men (approximately 12 percentage points) than for women (6

\footnotetext{
${ }^{11}$ First stage regressions indicate that the association between initial assignment and treatment is large and highly significant; $t$-values are greater than 37 far exceeding the rule of thumb for instrument relevance (Fstatistic > 10).

${ }^{12}$ As mentioned earlier, reported results are based on outcomes 15 months after registration into the experiment. Results are largely unaltered when this restriction is removed and outcomes measured on the last date of registration, regardless of when participants entered introduction programs. The program effect of TIP participation increases to 5.3 percentage points while the program effect on PES training programs decreases to 7.9 percentage points. These results are in line with the idea that participants have had more time to enter the labor market (and complete training programs).
} 
percentage points). Although the selection of female immigrants who enter introduction programs may have weaker merits on average than newly-arrived male immigrants (not supported by data on education levels) and are perhaps less job-ready, these results suggest that the innovations introduced within the trial introduction program do not appear to help newlyarrived female immigrants in entering the labor market. It is possible however that the types of programs offered to female participants of TIP as well as intensive counseling and coaching will yield positive results in the long run. ${ }^{13}$

-- Table 5 here --

\section{Program Effects on Duration to Achieved Outcomes}

Another aim of the trial introduction program was to speed up transitions from introduction programs to, above all, regular employment. ${ }^{14}$ On average, participants in TIP exit for regular employment later than participants in regular introduction programs (287 days compared to 255 days respectively). Duration in introduction programs is measured from initial registration at the PES office until registration as having achieved one of the stipulated outcomes. Average differences do not take into consideration the distribution of duration in introduction programs. It is possible for example that those with strong merits exit both types of introduction programs equally fast while participants in the trial program with weaker merits exit for employment after longer program participation in comparison to similar participants in regular programs who do not exit for employment at all.

Duration models on each outcome were estimated using multiple risk Cox Proportional Hazards models. Results (hazard ratios) are reported in Table 6 for the entire sample as well as separately by gender. Results indicate no significant differences between the treatment and control group in transitions to regular employment. No differences were found in separate

\footnotetext{
${ }_{13}$ A follow-up evaluation of TIP one year after program participation is scheduled.

${ }^{14}$ Introduction programs are administered at the municipal level implying large variation between municipalities in how these programs are set up. This includes the formal length of introduction programs, i.e., how long newly arrived immigrants are allowed to participate in ordinary introduction programs before being transferred to regular PES services. Municipals are however reimbursed by federal authorities only for costs incurred by introduction programs for a maximum of 24 months (based on a fixed compensation scheme per program participant). Although introduction programs may continue beyond this 24 month limit, the costs for longer programs are transferred to municipal coffers. The trial introduction program was however offered only for a maximum of 12 months after which remaining participants were transferred to regular introduction programs within the municipality.
} 
estimation by gender either suggesting that there is no program effect on transitions to regular employment. Hazard ratios are positive but not significant.

-- Table 6 here --

The Nelson-Aalen cumulative hazard function is plotted in Figure 1 showing the risk at any given time of exiting introduction programs for regular employment, given survival up to this time. The cumulative hazard estimate confirms that during the first 200 days, transition rates to regular employment were similar between participants in TIP and participants in regular introduction programs. Thereafter transition rates increase for participants in TIP relative to the control group, in particular during the last few months of the observation period. ${ }^{15}$

-- Figure 1 here --

A significant program effect was found in terms of earlier transitions to subsidized labor and PES training programs. The program effect on duration to subsidized labor is however driven by results for men. No program effect on transitions to subsidized labor was found for female participants of TIP. The program effect on transitions to PES training programs exists for both male and female participants. See Figure 2 and 3 for estimates of cumulative hazard functions for respective outcome.

-- Figure 2 and 3 here --

These results suggest that PES caseworkers within the trial program are more successful in pushing program participants into training programs and subsidized labor (men) in comparison to regular introduction programs, perhaps as a consequence of lower caseloads or due to better information concerning the training needs of participants. The question to answer in a future follow up study is to what degree earlier participation in subsidized labor programs as well as greater and faster access to PES training programs translates to higher subsequent sustainable employment in the regular labor market. Intensive coaching and counseling may also have promoted better matches between individual training needs and PES training programs, further strengthening subsequent employability in the regular labor market.

\footnotetext{
${ }^{15}$ The horizontal line in Figure 1 indicates the 365 cut-off date for participation in TIP. Outcomes are measured up until 15 months from initial registration in the experiment.
} 
In order to further explore the possibility that intensive counseling and coaching promoted better matches between individual needs and training programs, duration models on transitions to regular employment were re-estimated controlling, in separate estimation, for the number of different intermediary programs participants took part in during the course of introduction programs, the number of visits to PES caseworkers, and a full set of controls for type of PES training program (measured as a zero/one variable if the individual ever participated in respective type of program). In total there are 15 broad types of intermediary PES programs. See Table A3 in the Appendix for the proportion of TIP participants and control group participants in each type of program. Note that the table also includes the 5 categories which constitute the measure for regular employment. Notable differences include that a considerably higher proportion of participants in TIP have taken part in trainee programs, trial employment programs and PES training programs (both regular and preparatory) in comparison to the control group. In addition, a larger proportion of TIP participants were noted as taking part in activities indicating greater caseworker involvement, i.e. guidance and job search skills.

Results for extended duration models on transitions to regular employment are reported in Table 7. Model 1 (column 1) reports results for the basic model controlling only for conditional randomization (as also shown in Table 6). Model 2 adds a control for the number of programs which participants have taken part in. Reported results of no treatment effect on transitions to regular employment are unaltered. In addition, number of programs is not significantly correlated with transitions to regular employment. Including a control for number of visits with PES caseworkers in estimation (model 3) yields a positive treatment effect on regular employment. On average, participants of TIP have 22.2 visits with PES caseworkers during the observation period in comparison to the average of 13.2 visits for the control group. More intensive counseling and coaching can lead to better and quicker matches to relevant PES training programs, faster validation of home country educations and work experience, and greater support in the job search process, all of which may facilitate more rapid transitions to regular employment. Number of visits can, however, also reflect a greater need on the part of participants with weak skills for support which would then suggest a negative correlation between number of visits and transitions to employment. As shown in Table 7, number of visits is negatively correlated with transitions to employment. A positive treatment effect when controlling for number of visits suggest that these visits are more beneficial for participants in TIP. 
Finally, column 4 reports results for a model that includes controls for the type of program participants took part in during introduction programs. Again, a strong program effect for participation in TIP on transitions to regular employment emerges. Given the same broad type of programs, participants in TIP have significantly greater transitions to regular employment suggesting either that matches between individual needs and types of programs were better within TIP, perhaps as a consequence of more intensive contacts with PES caseworkers, or that TIP participants took part in higher quality programs (within the broad categories controlled for in estimation), facilitating transitions to regular employment.

\section{Conclusions}

This study evaluates a trial introduction program (TIP) for newly-arrived immigrants to Sweden that ran from October 2006 to June 2008, within three Swedish counties set up as an experiment with random program assignment. The purpose of the trial program was to considerably shorten the time from granted permanent residency to regular employment in the Swedish labor market via a number of innovations structured to meet the main criticisms of traditional introduction programs. Results in this study are based on participants that had the possibility of taking part in introduction programs (trial or ordinary) for a full 12 months plus an additional three months thereafter to establish themselves in the labor market.

Results from linear probability models measuring the last registered outcome 15 months after registration into introduction programs, indicate significant and positive treatment effects on the probability of being regularly employed as well as a positive program effect on enrollment probabilities into PES training programs. Participants in TIP had approximately 4 percentage point higher probabilities of being regularly employed at the end of the observation period and 10 percentage point higher probabilities of being enrolled in PES training programs in comparison to participants in regular introduction programs (the control group). Employment results are driven by treatment effects for men while results concerning PES training exist for both male and female participants, though the effect for men is twice as large as the effect for women.

Duration models estimating the hazard of exiting introduction programs show no program effect for transitions to regular employment. A treatment effect is found for hazards to subsidized labor (for men) and PES training programs. Additional estimation on hazards to 
regular employment controlling for number of visits with PES caseworkers and type of intermediary PES program, however, yields positive treatment effects. This suggests that more intensive counseling and coaching yields better matches between individual needs and training programs as well as a sorting to potentially better programs that foster more rapid transitions to regular employment. This result is in line with an earlier study on supported employment methods (Åslund and Johanssson, 2006) suggesting that intensive counseling and coaching is an effective method for improving the employment chances of unemployed (and newlyarrived) immigrants.

Results for female participants are less favorable than for male participants as no program effect was found for female participants in terms of regular employment. The question to answer is whether the intensive counseling and coaching within TIP will pay off in terms of greater employment chances in the long run. In addition, significant treatment effects on enrollment into intermediate PES training programs need to be followed up for both male and female participants in order to ascertain to what degree greater and faster access to PES training programs leads to higher subsequent employment rates.

A four percentage point increase in employment probabilities for program participants is at first glance a small effect. However, it is important to remember that the base is also very small. The Board of Integration, based on data from 2006, calculated that only five percent of female participants in introduction programs and ten percent of male participants were regularly employed one year after granted residency permits (Board of Integration, 2007). An increase of more than 5 percentage points found for male participants in TIP therefore implies a more than 50 percent improvement in employment rates in comparison to traditional introduction programs. Within the experiment discussed here, 9 percent of the control group was registered as regularly employed at the end of the observation period. An increase of 4 percentage points in employment probabilities for TIP participants therefore implies an improvement of approximately 44 percent in employment rates. In addition, treatment effects may be underestimated as the innovations introduced in the trial program may have spilled over to the work practices of PES caseworkers active within regular introduction programs at the same PES office. For example, improved cooperation and coordination with municipal programs for newly-arrived immigrants affected both types of introduction programs at any given PES office. As such, participants in regular introduction programs have to a degree also been treated implying that program effects may be larger than those reported here. 


\section{Tables and Figures:}

Table 1: Participating Counties in Each Municipality

\begin{tabular}{ll}
\hline County & Participating Municipality \\
\hline Stockholm & Botkyrka \\
& Södertälje \\
& Huddinge \\
\hline Kronoberg & Växjö \\
& Ljungby \\
& Lessebo \\
Skåne & Landskrona \\
& Kristianstad \\
& Helsingborg \\
\hline
\end{tabular}

Table 2: Definition of Outcome Variables

\begin{tabular}{ll}
\hline Outcome & Definition \\
\hline Regular Employment & $\begin{array}{l}\text { Deregistered for a permanent job position, } \\
\text { temporary job position or return to previous } \\
\text { job position; or registered job search status as } \\
\text { part-time employed or in a temporary } \\
\text { position. }\end{array}$ \\
& $\begin{array}{l}\text { Deregistered for subsidized employment } \\
\text { (Samhall)*; or registered job search status as } \\
\text { participant in a PES wage subsidized }\end{array}$ \\
& $\begin{array}{l}\text { employment program (either job practice or } \\
\text { wage subsidized employment). }\end{array}$ \\
& $\begin{array}{l}\text { Deregistered for participation in educations } \\
\text { not provided by the PES. }\end{array}$ \\
Registered job search status as participant in a \\
Regular Education & $\begin{array}{l}\text { PES provided education or training program } \\
\text { (including apprenticeship training) }\end{array}$ \\
\hline
\end{tabular}

* Samhall is a public Swedish organization assigned to provide meaningful work to the disabled.

Table 3: Unweighted Sample Means

\begin{tabular}{lcc}
\hline Outcome (\%): & $\begin{array}{c}\text { Trial Introduction } \\
\text { Program (treatment) }\end{array}$ & $\begin{array}{c}\text { Regular Introduction Program } \\
\text { (control) }\end{array}$ \\
\hline Regular Employment & $13.7^{* *}$ & 9.4 \\
Subsidized Employment & 7.4 & 5.9 \\
Regular Education & $3.0^{*}$ & 1.8 \\
PES Training & $11.2^{* * *}$ & 2.4 \\
Total & $35.0 * * *$ & 19.4 \\
\hline No. of observations & 995 & 340 \\
\hline Note: *** indicates significant differences between treatment (TIP) and control group at the 1 percent level, ** at \\
the 5 percent level and * at the 10 percent level.
\end{tabular}


Table 4: Treatment Effect of Participation in TIP

\begin{tabular}{lcc}
\hline Outcome & Linear Probability Models \\
\hline & Model 1 & Model 2 \\
Regular Employment & 0.050 & 0.041 \\
& $(0.023)^{*}$ & $(0.019)^{*}$ \\
Subsidized Employment & 0.010 & 0.010 \\
& $(0.019)$ & $(0.018)$ \\
Regular Education & 0.007 & 0.006 \\
& $(0.008)$ & $(0.009)$ \\
PES Training & 0.109 & 0.103 \\
& $(0.033)^{* *}$ & $(0.029)^{* * *}$ \\
No. of observations & 1335 & 1335 \\
\hline
\end{tabular}

Note: Model 1 includes controls for gender, PES office registration and date of registration. Model 2, in addition, controls for age, education and municipality. Standard errors (in parenthesis) are clustered at the PES office level. *** indicates significant program effects at the 1 percent level, ** at the 5 percent level and $*$ at the 10 percent level.

Table 5: Treatment Effect of Participation in TIP, by Gender Outcome Linear Probability Models

\begin{tabular}{lcc|cc}
\hline & \multicolumn{2}{c|}{ Female } & \multicolumn{2}{c}{ Male } \\
& Model 1 & Model 2 & Model 1 & Model 2 \\
Regular Employment & -0.008 & -0.007 & 0.069 & 0.056 \\
& $(0.037)$ & $(0.037)$ & $(0.029)^{* *}$ & $(0.023)^{* *}$ \\
Subsidized Employment & 0.023 & 0.022 & 0.003 & 0.001 \\
& $(0.021)$ & $(0.022)$ & $(0.023)$ & $(0.021)$ \\
Regular Education & 0.036 & 0.038 & -0.000 & -0.002 \\
& $(0.026)$ & $(0.027)$ & $(0.005)$ & $(0.005)$ \\
PES Training & 0.058 & 0.060 & 0.118 & 0.118 \\
& $(0.017)^{* *}$ & $(0.019)^{* *}$ & $(0.037)^{* *}$ & $(0.034)^{* * *}$ \\
\hline No. of observations & 375 & 375 & 960 & 960 \\
\hline Note: Model 1 includes controls for gender, PES office registration and month of registration. Model 2, in \\
addition, controls for age, education and municipality. Standard errors (in parenthesis) are clustered at the PES \\
office level. *** indicates significant program effects at the 1 percent level, ** at the 5 percent level and * at the \\
10 percent level.
\end{tabular}

Table 6: Treatment Effect of Program Participation on Duration to Achieved Outcomes (hazard ratios).

\begin{tabular}{lccc}
\hline Outcome & All & Women & Men \\
\hline Regular Employment & 1.343 & 0.812 & 1.367 \\
& $(0.306)$ & $(0.432)$ & $(0.341)$ \\
Subsidized Employment & $1.781^{* *}$ & 1.286 & $1.766^{* *}$ \\
& $(0.466)$ & $(1.345)$ & $(0.478)$ \\
Regular Education & 1.817 & 1.623 & 5.211 \\
& $(0.841)$ & $(0.414)$ & $(5.801)$ \\
PES Training & $4.632^{* * *}$ & $2.3 \mathrm{e}+15^{* * *}$ & $4.223^{* * *}$ \\
& $(1.452)$ & $(1.20 \mathrm{e}+15)$ & $(1.340)$ \\
\hline Antal observationer & 1334 & 375 & 959 \\
\hline Note: Estimated models control for gender PES office registration and month of registration. Reported \\
coefficients are hazard ratios measuring the difference in the the risk of exiting introduction programs between \\
participants in TIP and participants in the control group. Standard errors (in parenthesis) are clustered at the PES
\end{tabular}


office level. *** indicates significant differences between treatment (TIP) and control group at the 1 percent level, $* *$ at the 5 percent level and $*$ at the 10 percent level.

Table 7: Treatment Effect of Program Participation on Duration to Regular Employment (hazard ratios).

\begin{tabular}{lcccc}
\hline & $\mathbf{( 1 )}$ & $\mathbf{( 2 )}$ & $\mathbf{( 3 )}$ & $\mathbf{( 4 )}$ \\
\hline TIP & 1.349 & 1.145 & $1.811^{* *}$ & $2.250^{* * *}$ \\
& $(0,307)$ & $(0.309)$ & $(0.480)$ & $(0.541)$ \\
No. of PES intermediary programs & No & 1.088 & No & No \\
& & $(0.057)$ & & No \\
No. of visits with PES caseworkers & No & $0.966^{* * *}$ & No \\
& No & No & No & Yes \\
\hline
\end{tabular}

Note: Estimated models control for gender PES office registration and month of registration. Standard errors (in parenthesis) are clustered at the PES office level. *** indicates significant differences between treatment (TIP) and control group at the 1 percent level, ** at the 5 percent level and $*$ at the 10 percent level.

\section{Figure 1: Regular Employment}

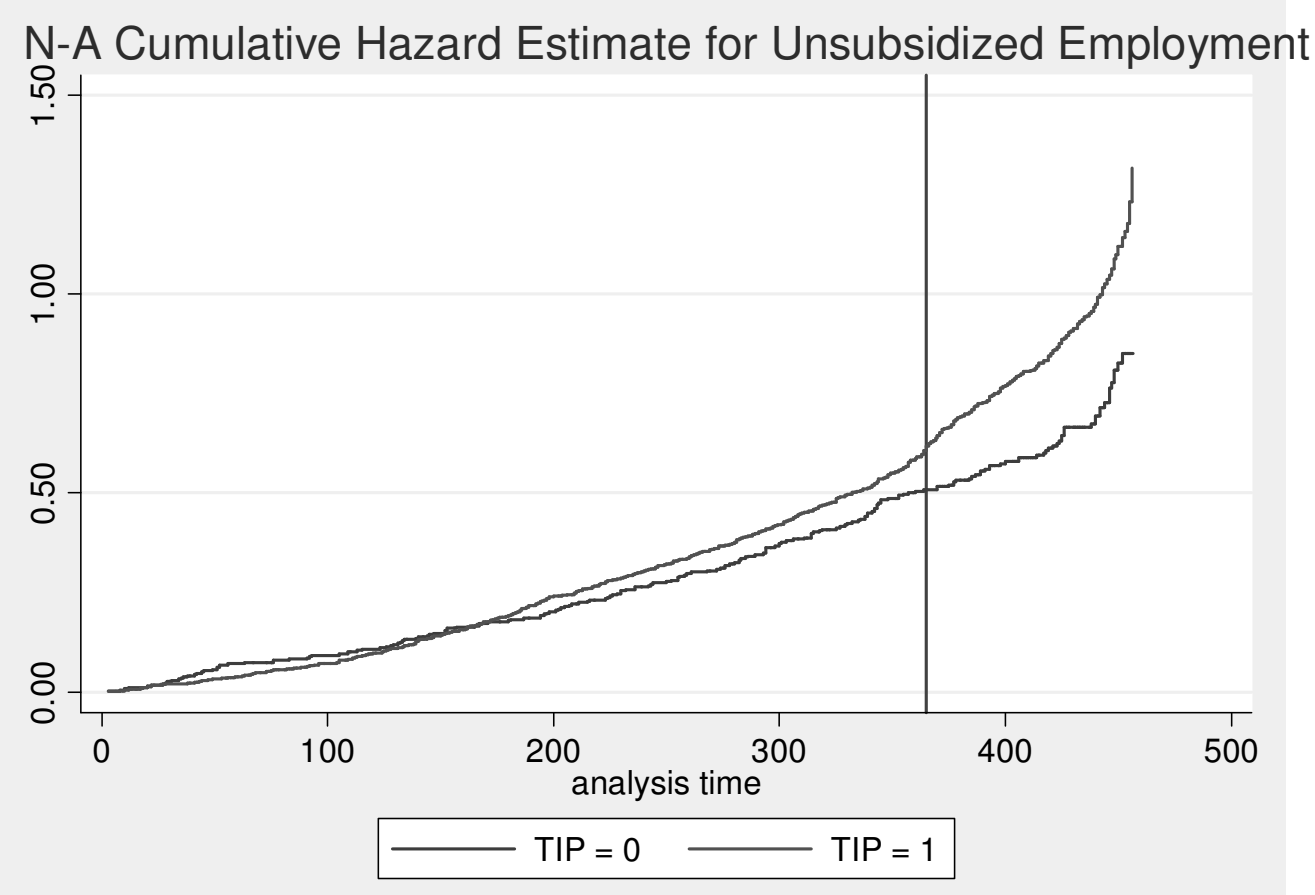


Figure 2: Subsidized Employment

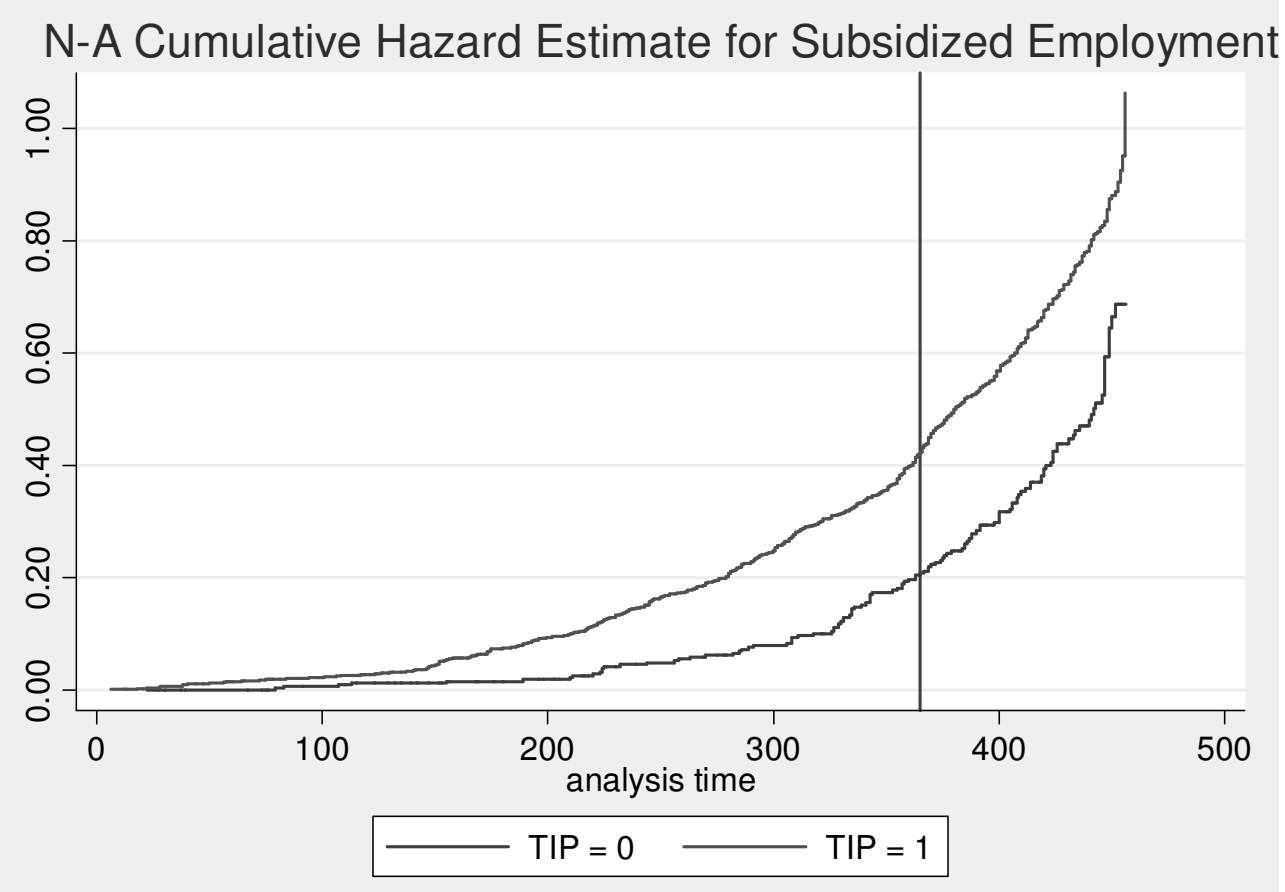

Figure 3: PES Training Programs 


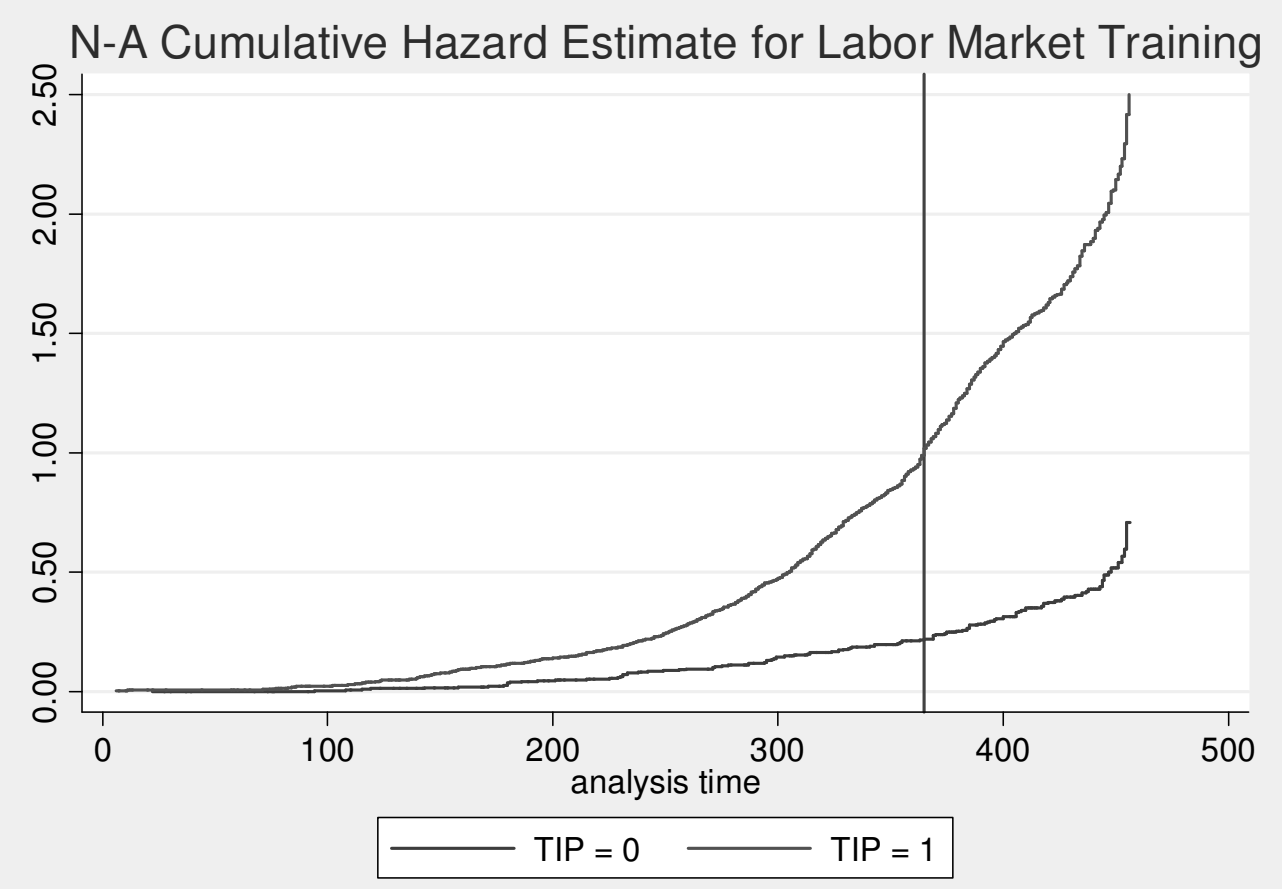




\section{Referenser:}

Andersson Joona, P. and L. Nekby (2009), 'TIPping the Scales towards Greater Employment Chances? Evaluation of a Trial Introduction Program (TIP) for Newly-Arrived Immigrants based on Random Program Assignment - Mid Program Results" SULCIS Working Paper 2009:4.

AMS (2007a), "Handlingsplan: Försöksverksamhet för vissa nyanlända invandrare N2006/3225/A", Arbetsmarknadsstyrelsen, Avdelningen för Samverkansfrågor, Göran Ferm.

AMS (2007b), "Definitioner inom AMV:s statistik. Historik över ett urval av våra begrepp", Uin 2007:1, Arbetsmarknadsstyrelsen.

E-mail från Monica Lindberg, Länsarbetsnämnden i Stockholm, 2007-11-19, 2007-12-07.

E-mail från Hans-Göran Johansson, Länsarbetsnämnden i Kronoberg, 2007-12-04.

E-mail från Allan Waktmar, Länsarbetsnämnden i Skåne, 2007-12-09.

Board of Integration (2002), "Hur togs de emot? Enkätundersökning om 28 kommuners introduktionsverksamhet för nyanlända 1999”, Board of Integrations Rapportserie 2002:4.

Board of Integration (2004), "Integration - var god dröj: Utvärdering av kommunernas introduktionsverksamhet för nyanlända invandrare mottagna 2001", Board of Integrations Rapportserie 2004:1.

Board of Integration (2005), "Introduktion för nyanlända invandrare - enkätundersökning 2004”, Board of Integrations Rapportserie 2005:1.

Board of Integration (2006), Rapport Integration 2005.

Board of Integration (2007), Statistikrapport 2007 - uppdatering av aktuella siffror, relevanta nyckeltal och indikatorer om integration.

Board of Integration, (2007b), "Ett förlorat år: En studie och analys av insatser och resultat under introduktionens första 12 månader", Board of Integrations stencilserie 2007:05.

Board of Integration (2007c), "Ett förlorat år: en studie och analys av insatser och resultat under introduktionens första 12 månader.

Clausen, J., E. Heinesen, H. Hummelgaard, L. Husted and M. Rosholm (2008), “The Effect of Integration Policies on the Time until Regular Employment of Newly Arrived Immigrants: Evidence from Denmark", forthcoming Labour Economics.

NTG-asyl \& Integration (2008); Henrik Emilsson,'Introduktion och integration av nyanlända invandrare och flyktingar. Utredningar, granskningar, resultat och bristområden" Asylmottagande i Fokus, En skriftserie från NTG-asyl \& integration. Nr. 7, 2008.

Riksrevisionen (2006), RiR 2006:19, ”Statliga insatser för nyanlända invandrare”. 
Schröder, L. (2007), "From Problematic Objects to Resourceful Subjects: An Overview of Immigrant-Native Labour Market Gaps from a Policy Perspective" Swedish Economic Policy Review, Vol. 14 (1): 7-32.

SKL (2006), "Introduktion - ett sätt att gära nyanlända delaktiga i svenskt arbets- och samhällsliv", Programberedningen för integration i arbetslivet.

SKL (2007a), "Introduktion av nyanlända - kartläggning av hinder", Programberedningen för integration i arbetslivet.

SKL (2007b), "Introduktion av nyanlända - förslag till mål och modeller", Programberedningen för integration i arbetslivet.

SOU 2003:75 Etablering i Sverige. Möjligheter och ansvar för individ och samhälle.

SOU 2008:58 Egenansvar - med professionellt stöd. Utredningen om nyanländas arbetsmarknadsetablering.

Svantesson, Elisabeth (2006), "Determinants of Immigrants Early Labor Market Integration", Handelshögskolan, Örebros universitet, Working Paper No. 2.

Svantesson, Elisabeth och Ted Aranki, (2006), "Do Introduction Programs Affect the Probability of Immigrants getting Work?", Handelshögskolan, Örebros universitet, Working Paper No. 3.

Regeringen (2007), Pressmeddelande 16 april 2007, Finansdepartementet, "Vårbudgeten 2007: En politik för fler i jobb och bättre möjligheter för företagande”.

Åslund, Olof, Robert Erikson, Oskar Nordström Skans och Anna Sjögren, (2007), "Ungdomars och invandrades inträde på arbetsmarknaden 1985-2003", IFAU rapport 2007:18.

Åslund, O. and P. Johansson (2006), "Virtures of SIN - Effects of an Immigrant Workplace Introduction Program" IFAU Working Paper 2006:7. Institute for Labour Market Policy Evaluation, Sweden. 


\section{Appendix}

Table A1: Multinomial Logit Estimation on Outcomes.

Reference category: no achieved outcome. Results reported as odds ratios.

\begin{tabular}{lcccc}
\hline & $\begin{array}{c}\text { Regular } \\
\text { Employment }\end{array}$ & $\begin{array}{c}\text { Subsidized } \\
\text { Employment }\end{array}$ & $\begin{array}{c}\text { Regular } \\
\text { Education }\end{array}$ & $\begin{array}{c}\text { PES } \\
\text { Training }\end{array}$ \\
\hline $\begin{array}{l}\text { Program Effect } \\
\text { (TIP) }\end{array}$ & 1.889 & 1.591 & 2.046 & 10.865 \\
\hline & $(0.554)^{*}$ & $(0.572)$ & $(0.710)^{* *}$ & $(2.406)^{* * *}$ \\
\hline
\end{tabular}

Number of observations: 1335

Note: Estimation includes controls for gender, PES office, month of registration, age, education and municipality. Standard errors (in parenthesis) are clustered at the PES office level. *** indicates significant differences between treatment (TIP) and control group at the 1 percent level, ** at the 5 percent level and $*$ at the 10 percent level.

Table A2: IV estimates of Program Effects (TIP)

\begin{tabular}{|c|c|c|}
\hline \multirow[t]{2}{*}{ Outcome } & \multicolumn{2}{|c|}{ IV-estimation } \\
\hline & Model 1 & Model 2 \\
\hline \multirow{2}{*}{ Regular Employment } & 0.068 & 0.056 \\
\hline & $(0.029) * *$ & $(0.029)^{*}$ \\
\hline \multirow[t]{2}{*}{ Subsidized Employment } & 0.019 & 0.013 \\
\hline & $(0.023)$ & $(0.024)$ \\
\hline \multirow[t]{2}{*}{ Regular Education } & 0.012 & 0.008 \\
\hline & $(0.015)$ & $(0.015)$ \\
\hline \multirow[t]{2}{*}{ PES Training } & 0.133 & 0.149 \\
\hline & $(0.020)^{* * *}$ & $(0.020) * *$ \\
\hline No. of observations & 1335 & 1335 \\
\hline \multirow{2}{*}{\multicolumn{3}{|c|}{$\begin{array}{l}\text { Note: Intention to treat (based on initial assignment) is used as } \\
\text { controls for gender, PES office registration and month of regis } \\
\text { education and municipality. Standard errors (in parenthesis) are } \\
\text { significant program effects at the } 1 \text { percent level, ** at the } 5 \text { perce } \\
\text { Table A3: Types of PES Programs, Sample Means }\end{array}$}} \\
\hline & & \\
\hline Category & TIP & Control \\
\hline Unemployed & 51.9 & 52.1 \\
\hline Unemployed/special needs & 95.8 & 97.1 \\
\hline Part time unemployed (unsubsidized employment) & 2.4 & 1.8 \\
\hline Employed by the hour (unsubsidized employment) & 5.7 & 5.0 \\
\hline Temporary employment (unsubsidized employment) & 5.4 & 2.3 \\
\hline New Start (unsubsidized employment) & 8.1 & 6.2 \\
\hline Employed but searching (unsubsidized employment) & 4.2 & 1.5 \\
\hline Wage subsidy & 0.1 & 0.0 \\
\hline Self employment subsidy & 0.3 & 0.0 \\
\hline Special employment subsidy & 0.3 & 0.0 \\
\hline Trainee program & 21.3 & 2.9 \\
\hline Trial employment program & 9.6 & 1.5 \\
\hline Youth program (ceased 2007-11-30) & 0.2 & 0.0 \\
\hline Labor market rehabilitation & 0.1 & 0.0 \\
\hline Activities- guidance/job search & 10.0 & 1.5 \\
\hline Project activites & 1.1 & 0.0 \\
\hline
\end{tabular}




\begin{tabular}{lcc}
\hline Validation & 3.5 & 0.3 \\
In Step program & 2.6 & 0.6 \\
PES training & 18.8 & 4.4 \\
PES initial training (preparatory) & 42.2 & 6.5 \\
\hline
\end{tabular}

Note: Sample means indicate participation in respective program at any time during the course of introduction programs. Participants can have multiple activities during the observation period. The high proportion registered as "unemployed with special needs" is due to the fact that almost all newly-arrived immigrants participating in introduction programs need Swedish language instruction before being relegated to other PES activities. 